\title{
Do cerrado ao mar: a Tradição Una no litoral do Espírito Santo
}

\author{
Paulo Roberto Gomes Seda \\ Universidade do Estado do Rio de Janeiro/ \\ Instituto de Arqueologia Brasileira
}

Christiane Lopes Machado

Rhea Estudos e Projetos

Gláucia Malerba Sene

Instituto de Arqueologia Brasileira

Bolsista de Pós-doutorado do FAPERJ; Museu Nacional / UFRJ

Laura da Piedade Ribeiro da Silva

Instituto de Arqueologia Brasileira

\section{Introdução}

O trabalho tem por finalidade apresentar os resultados obtidos com a escavação realizada para resgate arqueológico na área de Expansão do Terminal Especializado de Barra do Riacho, da empresa Portocel, localizada no Município de Aracruz, Estado do Espírito Santo, enfocando a análise cerâmica.

Além de cumprir a determinação legal de resgate prévio a implantação de um empreendimento em área com sítio arqueológico, a pesquisa resultou em novos dados para conhecimento da história de ocupação local.

As atividades foram iniciadas com o diagnóstico arqueológico, integrante do Estudo de Impacto Ambiental que avaliou a viabilidade do empreendimento $^{1}$. Nessa ocasião, foi constatado o potencial de ocorrência de sítios 
arqueológicos no local, sendo verificada a presença de alguns fragmentos de cerâmica. Foi então recomendado, dentre os programas ambientais, a realização da prospecção arqueológica, seguindo as etapas previstas na Portaria IPHAN n 230.

A prospecção ${ }^{2}$ cobriu integralmente a área do empreendimento, com sondagens realizadas a intervalos de 50 metros, sendo observados diversos pontos com vestígios cerâmicos em superfície e subsuperfície por uma área com cerca de 200 X 150 metros. Registrado como o sítio arqueológico Portocel, uma vez que o mesmo seria afetado, decidiu-se por sua escavação. A Figura 1 mostra a localização do Portocel, onde se insere o sítio arqueológico de mesmo nome.

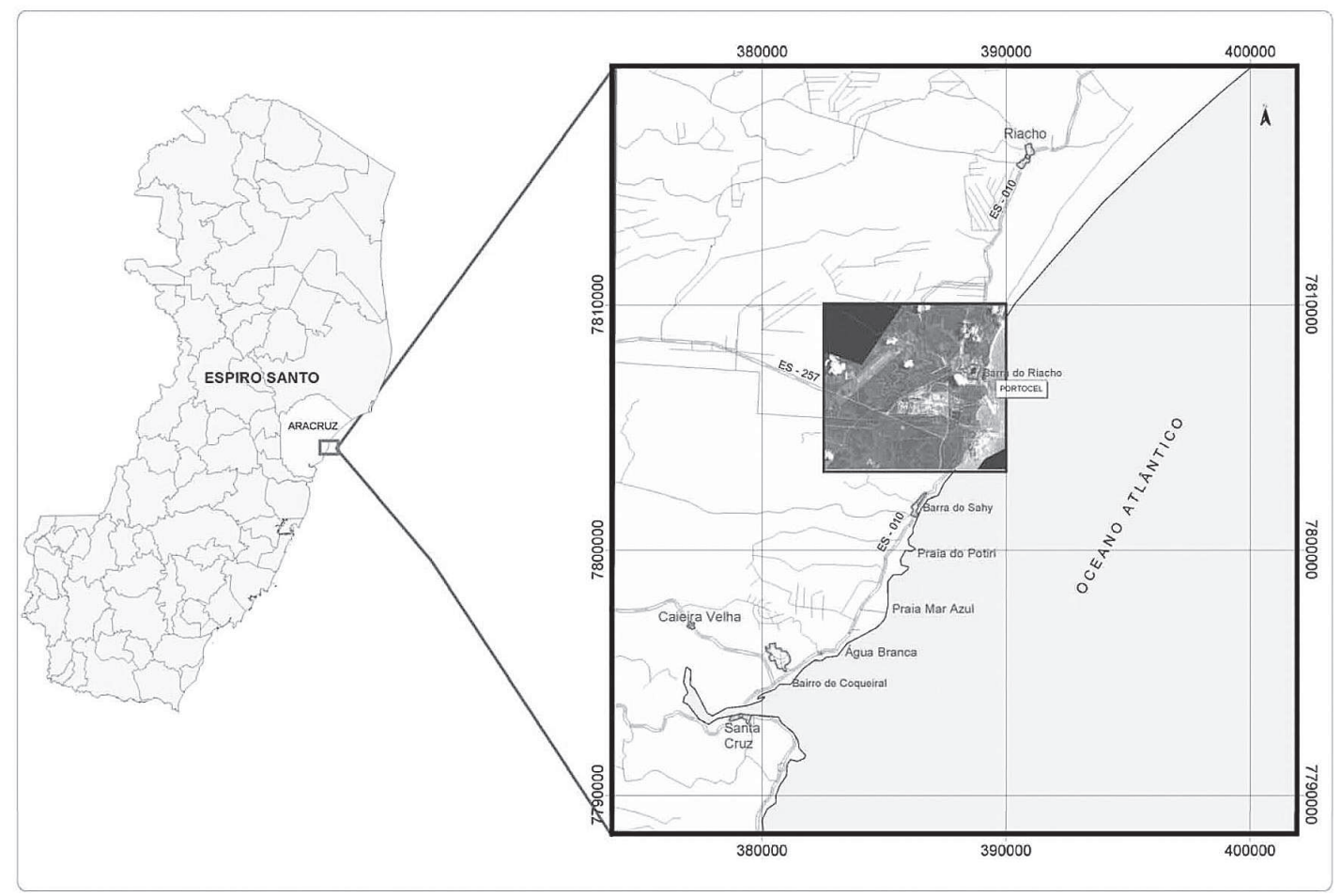

Figura 1: Mapa de localização do empreendimento.

\section{CONTEXTO AMBIENTAL}

A área do sítio arqueológico é plana, com solo argilo-arenoso. Há declive acentuado em direção sul e a leste, marcando o limite da área de tabuleiro com a planície costeira e fluvial.

O sítio está inserido em área bastante propícia à ocupação humana, com relevo plano sobre uma pequena elevação em relação ao nível do mar, junto a

\section{Maracanan}


um córrego, permitindo fácil acesso à água potável e aos recursos alimentares diversificados, fornecidos pelo rio, mar e pela mata existente no local originalmente. Acrescente-se ainda aqueles provenientes das atividades agrícolas do grupo.

O contexto arqueológico do sítio em questão já se apresentava bastante afetado por ações antrópicas anteriores, que perturbaram a distribuição espacial das ocorrências ao danificarem parcialmente a disposição das camadas estratigráficas. De acordo com $\mathrm{MACHADO}^{3}$, no Relatório do Levantamento Arqueológico, isto se deu principalmente pela utilização de maquinário durante as atividades de silvicultura, como o subsolador que alcança um metro de profundidade para revolvimento do solo.

\section{PROCEDIMENTOS E RESULTADOS DA PESQUISA}

\section{Escavação}

Com a intensificação das pesquisas durante o resgate, verificou-se que a área do sítio arqueológico é de aproximadamente 200 x 200 metros, havendo pequena ocorrência de material na área periférica.

Devido ao profundo corte no solo feito para a abertura de estrada na extremidade leste do sítio, formou-se um barranco que permitiu observar as camadas estratigráficas, e relacionar com segurança a ocupação arqueológica à camada superficial de solo marrom escuro.

O sítio arqueológico foi escavado segundo a metodologia de transects, linhas simétricas virtualmente traçadas numa direção e por decapagem em níveis artificiais de $10 \mathrm{~cm}$. Foi definido um marco zero na área central do sítio arqueológico e a partir dele marcados os transects a cada 20 metros, onde foram demarcados os cortes de 1 x 1 metro escavados, também a intervalos de 20 metros. 


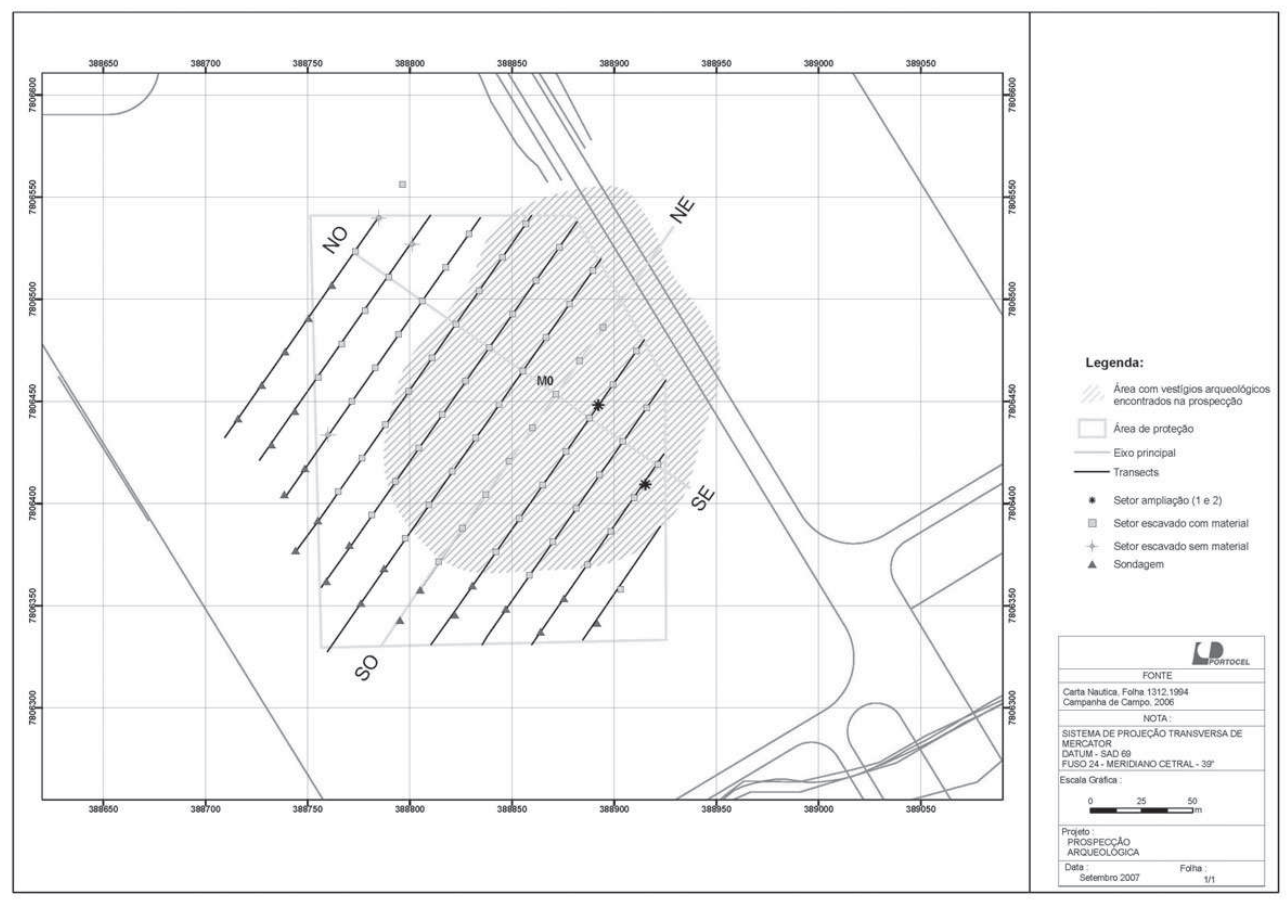

Figura 2: Planta do sítio arqueológico Portocel, de acordo com o observado na prospecção e setores escavados durante o resgate.

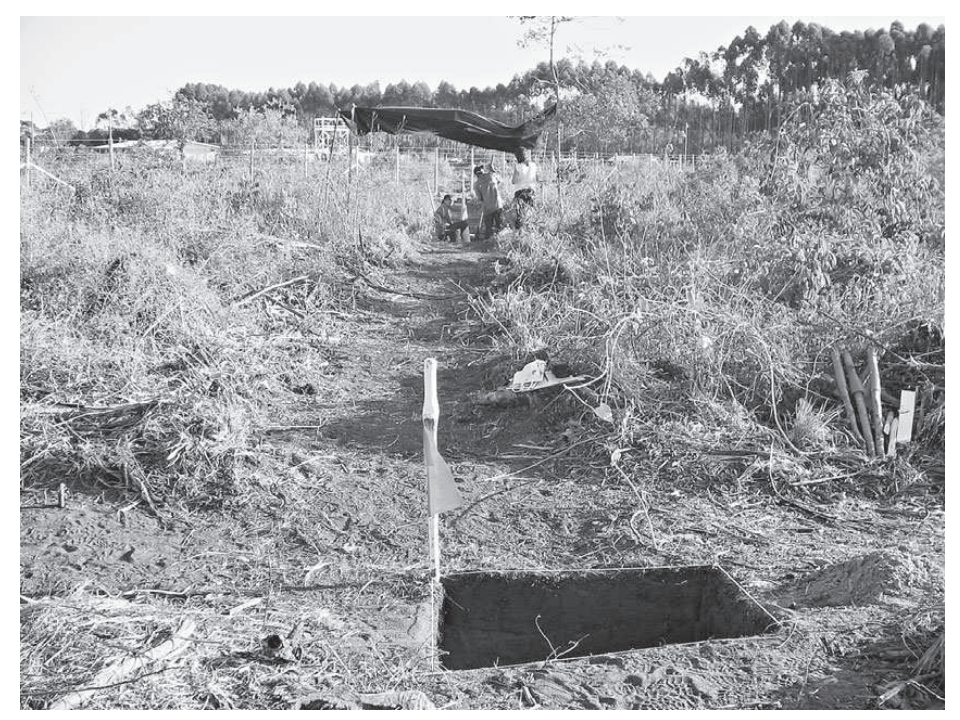

Figura 3: Escavação do Transect Noroeste.

Devido às condições de sedimentação e espessura da camada arqueológica, que atingia a profundidade máxima de $40 \mathrm{~cm}$ (solo areno-argiloso relativamente friável, com coloração variando do marrom escuro ao preto),

\section{Maracanan}


assentada sobre uma camada de argila amarelada extremamente compacta, profunda e culturalmente estéril, decidiu-se que esta seria a 'camada-guia' (camada geológica antiga e profunda) que definiria a paralisação da escavação dos setores. Mesmo assim ao ser atingida, era feita uma sondagem central em cada setor a fim de confirmar sua ocorrência e ausência de remanescentes culturais.

Nos quadrantes sul e oeste, ao final de cada transect, foram feitas sondagens com $25 \mathrm{~cm}$ de diâmetro e $60 \mathrm{~cm}$ de profundidade aproximadamente, objetivando a confirmação de que os vestígios estavam cada vez mais escassos nestas direções conforme indicava o resultado das escavações nessas porções do sítio. Assim, foram realizadas vinte e quatro sondagens e em nenhuma houve ocorrência de vestígios arqueológicos. A própria coloração e composição do solo mostravam-se bem diferentes do restante do sítio, ou seja, mais clara e com a camada de argila amarela - arqueologicamente estéril - cada vez mais próximo da superfície.

Foram escavados ao todo sessenta e oito setores de $1 \mathrm{x} 1 \mathrm{~m}$, dentre os quais apenas quatro situados nos quadrantes norte e oeste não apresentaram material cultural. Acrescente-se ainda que durante o processo de escavação foi possível perceber que a maior concentração de vestígios estava situada entre os transects nordeste e sudeste onde, além de fragmentos cerâmicos, lascas de quartzo, ósseo animal, foram encontrados dois vasilhames cerâmicos praticamente inteiros.

Nas áreas com maior concentração de vestígios culturais do sítio, ampliaram-se duas áreas de escavação, uma junto ao Setor SE-A-0 medindo 1 × 2 metros (Ampliação 1) e outra com 2 × 2 metros, adjacente ao setor S-C-1 (Ampliação 2), situadas respectivamente nos quadrantes sudeste e sul. Além de aumentar a amostragem geral de vestígios, tais ampliações também permitiram, após análise do material, conhecer melhor as porções do assentamento mais intensamente utilizadas pelas populações antigas que habitaram o local.

Foram realizadas três coletas de fragmentos cerâmicos para datação por termoluminescência nos setores S-B-2, nível 0/10 cm, S-C-1, 10/20 cm e na Ampliação 2, no nível $10 / 20 \mathrm{~cm}$, a fim de tentar situar cronológica e culturalmente as populações que outrora ocuparam o local e a região como um todo. 


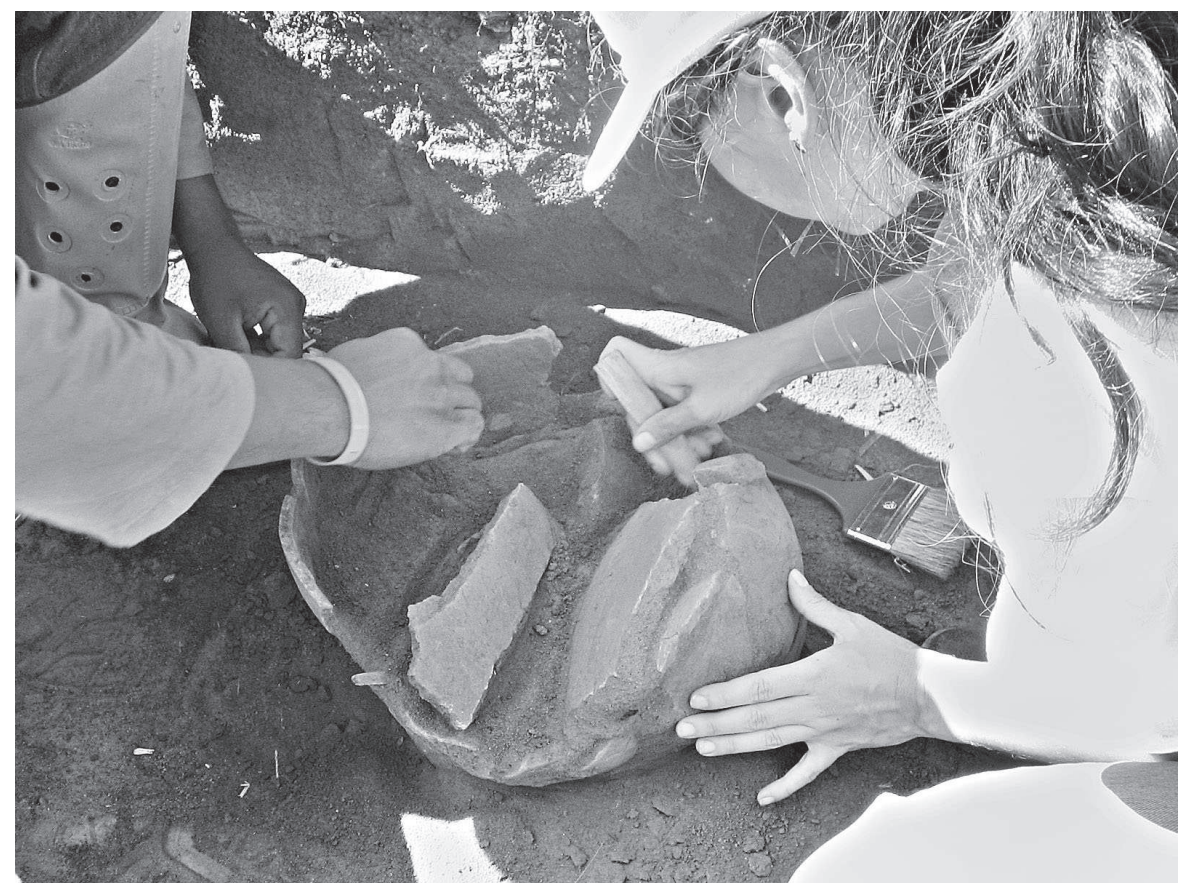

Figura 4: Escavação de vasilhame cerâmico

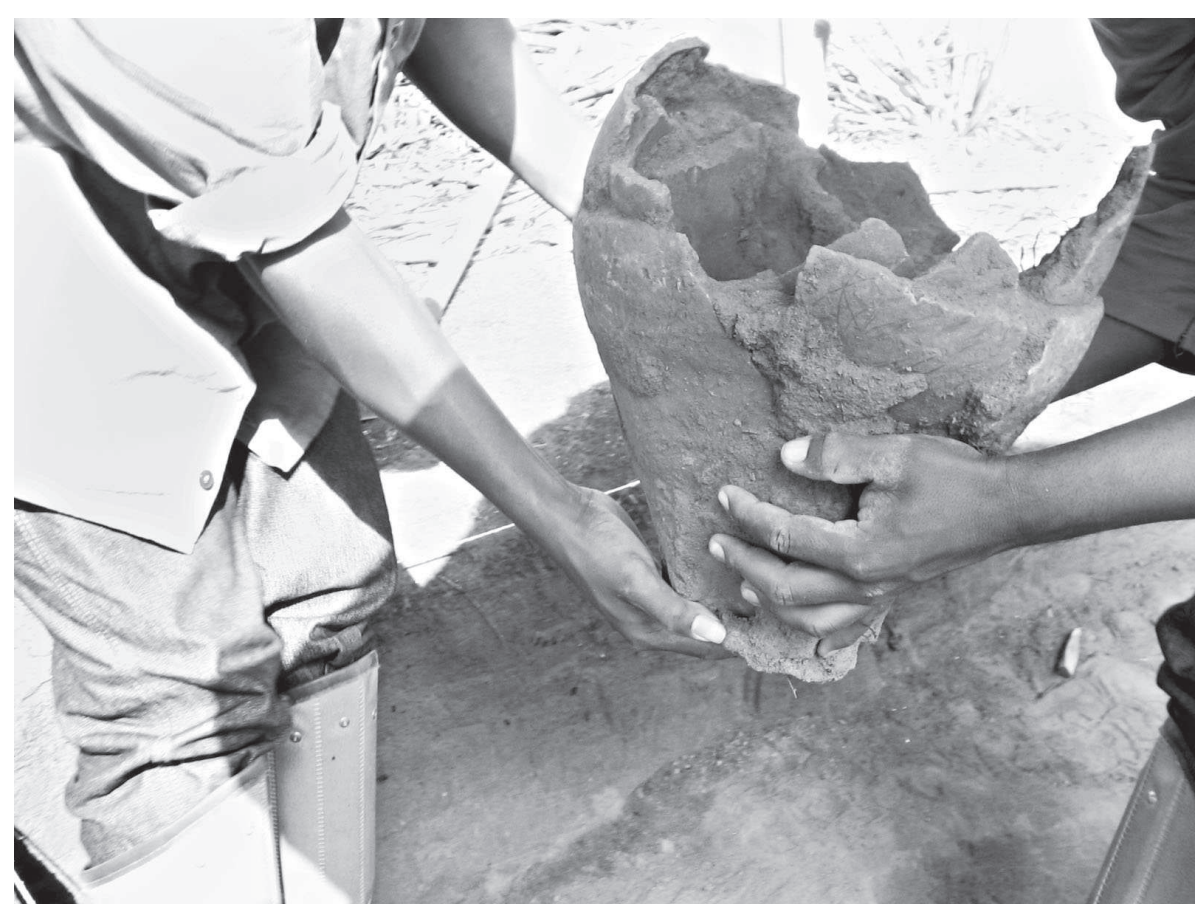

Figura 5: Retirada do vasilhame

$\mathrm{Na}$ área remanescente do sítio a nordeste da estrada que cortou sua extremidade, foi realizada uma ampla coleta de superfície em toda a sua extensão.

\section{Maracanan}


É uma área de declive medianamente acentuado em direção ao mar e camada de terra preta com $30 \mathrm{~cm}$ de espessura, sendo coletados fragmentos de cerâmica, malacológicos, pequenas lascas de quartzo, faiança do século XVIII e XIX, grés e vidro.

\section{LABORATÓRIO}

O material predominante foi o cerâmico, dentre os quais se destacam duas urnas funerárias remontadas, seguido do lítico, alguns fragmentos de malacológico e uns poucos exemplares de vestígios históricos (louça, vidro e grés).

Os vestígios cerâmicos e líticos encontrados durante a escavação estão relacionados a um grupo ceramista agricultor, indicando uma permanência maior do grupo no local em questão. Embora os sítios arqueológicos conhecidos para a região demonstrem uma vinculação direta à Tradição Aratu, a análise de laboratório demonstrou que há elementos culturais novos que devem ser considerados dentro do processo de ocupação do local.

Destacaram-se ainda alguns poucos vestígios culturais históricos superficiais coletados durante o resgate, tais como: faiança do século XVIII (oito fragmentos de pratos com decoração simples e artesanal em cor azul e marrom, junto à borda), além de três fragmentos de grés (cerâmica vitrificada) e vidro transparente (copos), possivelmente dos séculos XIX e XX respectivamente.

\section{Análise Cerâmica}

O material cerâmico encontrava-se bastante fragmentado, o que indica uma significativa perturbação no terreno do sítio.

Limpos e identificados, foram analisados 25.580 fragmentos (cacos). Além disto, foi possível restaurar parcialmente dois vasilhames, cujos fragmentos cerâmicos não foram contabilizados neste total, mas igualmente analisados.

$\mathrm{Na}$ análise, procurou-se identificar em cada caco o tratamento de superfície, o tratamento da pasta (método de execução, tempero, textura, dureza, cor, queima, simples, decorada) e a morfologia das bordas (tipo e boca). Inicialmente, os cacos foram separados em simples (sem decoração), decorados e bordas (simples e decoradas), procedendo-se as demais observações. No caso 
dos decorados e bordas, não foi feita a observação do tempero, mas procurando identificar o tipo de decoração existente e a possível forma reconstituível a partir da borda. Os cacos simples totalizaram 23.350 cacos e os decorados 229 cacos, em ambos incluíndo-se as bordas. Foram obtidos os seguintes resultados:

Método de Manufatura

em todos os cacos examinados a técnica de confecção observada é a acordelada, com roletes redondos (poucos em bisel), normalmente com a solda completa, junções bem pressionadas e obliteradas. Não foi observada em nenhum caco a técnica modelada, foram, no entanto, identificados seis apliques que, certamente, foram modelados.

\section{Tempero}

A análise da cerâmica em lupa binocular revelou um tempero predominantemente de areia grossa (grãos acima de $1 \mathrm{~mm}$ ), o que está de acordo com o terreno e a posição espacial do sítio (próximo ao mar). Observou-se ainda a presença de muito quartzo (cristalino e leitoso, com dimensões variadas), alguma hematita e, em alguns casos, carvão e mica (muito pouca). Durante a análise, a cerâmica simples não foi separada por tipo de tempero (areia grossa e areia fina, quartzo grosso e quartzo fino, etc.), o que faz com este tipo (simples) tenha sempre um percentual muito alto, em todos os setores.

\section{Tratamento de superfície}

A grande maioria dos cacos analisados encontrava-se já bastante erodidos, o que acarretou a lixiviação de boa parte da superfície. Tal fato tornou difícil a observação do tratamento de superfície. Contudo, naqueles em que isto foi possível, observou-se a presença de uma superfície alisada, tato externa quanto internamente, o que indica que isto fosse uma pratica comum. Além disso, em 0,21\% dos cacos observou-se a presença de Polido-Estriado e em 0,02\% a presença de Banho Vermelho, que podem ser vistos como tratamento de superfície.

\section{Maracanan}


Textura e Dureza (resistência)

A maioria dos cacos apresentava uma textura coesa (queima homogênea, sem bolhas, sem rachaduras ou trincamentos) e uma boa resistência mecânica (dureza e resistência mediana ao risco, quebra ou choque, não se fragmentando com facilidade ou 'esfarinhando'). A espessura das paredes dos cacos está entre $3 \mathrm{~mm}$ e $18 \mathrm{~mm}$, ficando a maioria em torno dos $10 \mathrm{~mm}$, evidenciando a predominância de vasilhames de paredes finas. Tais características, associadas a queima, que será tratada adiante, e ao tratamento de superfície, indicam um bom domínio da tecnologia cerâmica. Deve-se ressaltar, no entanto, que estas observações somente são válidas para os cacos que não sofreram um processo severo de erosão, onde toda a textura e resistência são alteradas.

Cor

Normalmente associada ao processo de queima, variando do alaranjado ao negro, predominando os cacos de tendência marrom.

\section{Queima}

Na maioria dos cacos, observou-se, nas paredes, uma oxidação incompleta e não é rara a queima de tendência redutora (sem a presença do oxigênio). A incidência de cacos com queima de tendência oxidante (com a presença do oxigênio), também não é pequena, mas bem menos popular. No caso dos núcleos, porém, todos são negros, indicando a queima redutora. Peças com manchas negras (redução localizada) são comuns, indicando terem sido queimados encostados em algum apoio. A maior incidência de tendência redutora (oxidação incompleta e queima redutora p.p.d.) reforça as observações sobre o domínio da tecnologia cerâmica, uma vez que este tipo de queima requer um controle muito maior, além de uma temperatura mais alta.

\section{Tipos estabelecidos}

Durante a análise, os cacos foram separados em decorados e não decorados (simples). O tipo simples é bem mais popular, enquanto que, nos 
decorados, embora reduzidos, observou-se uma significativa variedade de decorações, contudo todas elas do tipo plástica (alterações da superfície da cerâmica). Não se registrou, portanto, decoração pintada. Alguns cacos apresentavam mais de um tipo de decoração e, neste caso, optou-se por computá-lo na decoração predominante (ou mais evidente). Os tipos estabelecidos são os seguintes:

A) Simples (S): 25.350 cacos ou 99,1\% do material, incluindo 766 bordas, caracterizado pela ausência de decoração .

B) Aplicado (A): 6 cacos ou 0,02\% do material (2,62\% dos decorados), caracterizados por bolas ou tiras, que eram aplicadas na superfície da cerâmica, formando efeitos variados. Todos os apliques foram encontrados soltos e não se concentravam em um determinado setor.

C) Banho Vermelho (BV): 8 cacos (sendo 2 bordas) ou 0,03\% do material (3,49\% dos decorados), caracterizado pela aplicação, anterior a queima, de uma camada delgada de pigmentos minerais (neste caso vermelho) na superfície do vasilhame. Foram identificados BV na face externa, na face interna e ambas as faces dos $\operatorname{cacos}^{5}$. Não foram observadas concentrações do tipo.

D) Corrugado (C): 14 cacos (7 bordas) ou 0,05\% do material (6,11\% dos decorados), caracterizado pela sobreposição dos roletes, na face externa, durante o acordelamento. A maior concentração do tipo ocorre no setor OC-1 (5 cacos). Observou-se, nesta decoração, as seguintes combinações:

E) Corrugado + Entalhado;

- Corrugado + Ponteado e

- Corrugado + Ungulado.

F) Corrugado Espatulado (CE): 7 cacos (2 bordas) ou 0,02\% do total do material (3,05\% dos decorados), caracterizado pela decoração em que as corrugações, estreitas e longas, foram feitas provavelmente por espátulas. Não foram observadas concentrações.

G) Entalhado (E): 11 cacos (2 bordas) ou 0,04\% do material (4,8\% dos decorados), caracterizado por pequenos cortes (entalhes) executados no lábio do vasilhame ou em qualquer outra parte do mesmo. Também não foram observadas concentrações.

H) Inciso (I): 53 cacos (10 bordas) ou 0,20\% do material (23,14\% dos decorados) é a segunda decoração mais popular no sítio, consistindo em incisões

\section{Maracanan}


praticadas por intermédio de instrumentos variados, antes da queima, variando em comprimento, largura e profundidade, podendo apresentar secções regulares ou irregulares. O setor OC-1 $(9$ cacos) tem a maior concentração deste tipo. Foi a decoração que apresentou maior número de variações:

- Inciso Duplo;

- Inciso Múltiplo (mais de duas linhas incisas);

- Inciso Duplo + Entalhado;

- Inciso Duplo + Ponteado;

- Inciso Paralelo (linhas feitas paralelamente);

- Inciso + Ponteado e

- Inciso + Ungulado.

I) Polido-Estriado (PE): 56 cacos ( 3 bordas) ou 0,21\% do material (24,45\%), decoração mais popular, é um complemento do alisado, na qual o polimento deixa estrias na superfície da cerâmica, dando certa aparência de "vitrificado". Infelizmente, as maiores concentrações de Polido-Estriado (17 e 56 cacos) foram encontradas no barranco (podem, inclusive fazer parte de um mesmo vasilhame) 6 .

J) Ponteado (P): 9 cacos (1 borda) ou 0,03\% do material (3,93\% dos decorados), decoração feita com pontas, deixando marcas independentes, podendo ser de várias formas e tamanhos, embora sejam, na maior parte arredondadas e pequenas. Não foram observadas concentrações do tipo.

K) Roletado (R): 12 cacos (2 bordas) ou 0,04\% do material (5,24\% dos decorados), caracterizado pela conservação dos roletes de confecção do vasilhame, sem pressionar e alisar sua superfície externa. As maiores concentrações dos tipos foram observadas nos setores NO-A0 e NB-1. As seguintes variações foram observadas:

- Roletado + Inciso;

- Roletado + Inciso Paralelo;

- Roletado + Ponteado e

- Roletado + Ungulado.

L) Ungulado (U): 53 cacos (16 bordas) ou 0,20\% do material (23,14\% dos decorados), segunda decoração mais popular (juntamente com o Inciso), consiste na impressão com a ponta das unhas, de marcas agrupadas em diversas posições, na superfície cerâmica. Está decoração apresentou uma concentração significativa no setor OC-1: 16 cacos.

Janeiro | Dezembro 2011 


\section{SÍTIO PORTOCEL: DECORAÇÕES}

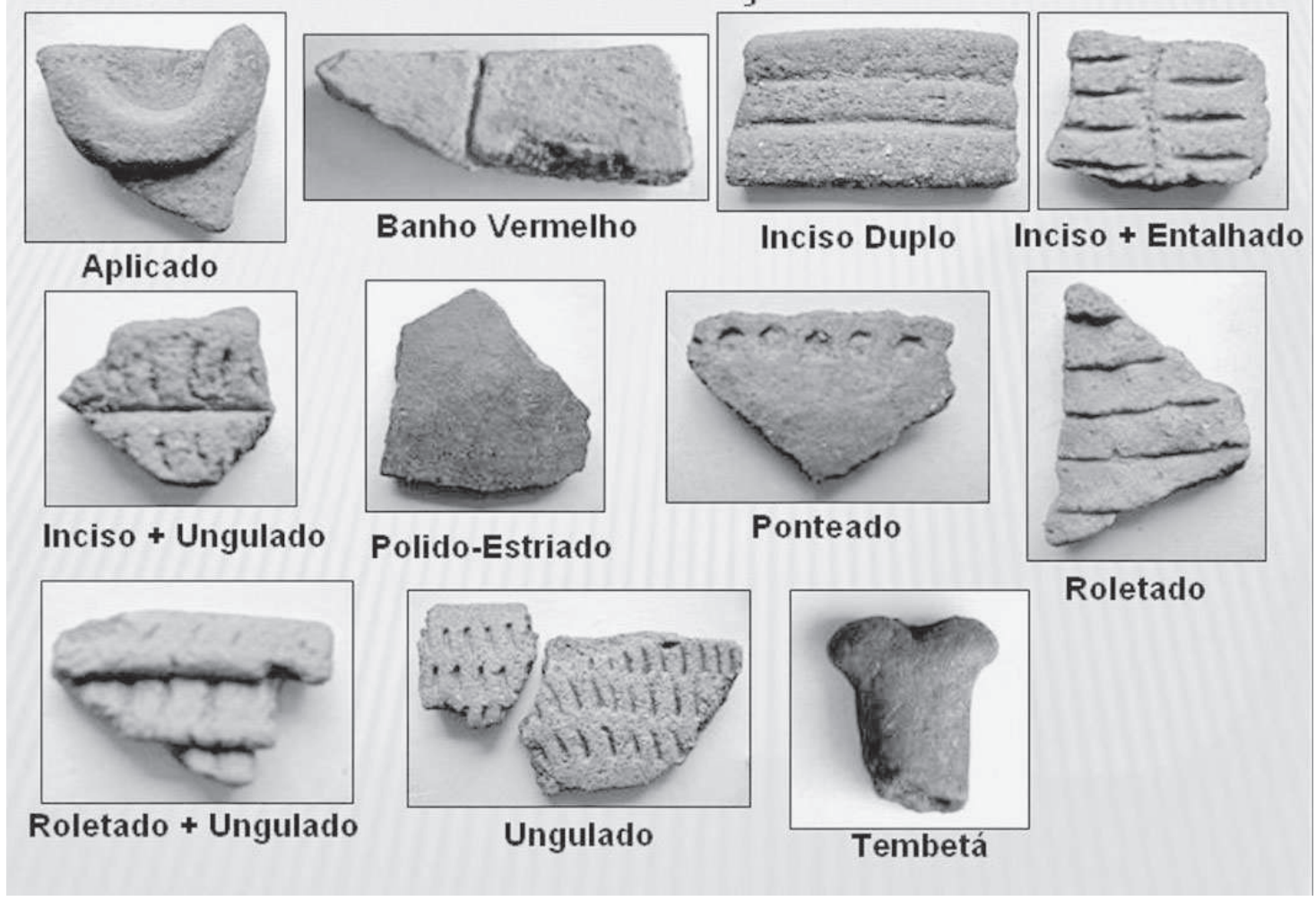

Figura 6: tipos cerâmicos decorados reconhecidos na análise do sítio Portocel.

\section{FORMAS RECONSTITUIIDAS}

O material analisado apresentou um avultado número de fragmentos de bordas: 811 , sendo 45 decoradas, sendo poucos os setores em que estas não ocorreram. Infelizmente, apesar deste alto número de bordas, a maioria dos fragmentos além de pequenos, são de bordas retas, o que dificulta a reconstituição.

Daqueles que permitiram reconstituição, percebe-se uma predominância absoluta dos vasos (67,64\%), em detrimento das tigelas (32,35\%). Pratos não foram identificados. Todas as tigelas são Tigelas Fundas, enquanto nos vasos 47,82\% são Vasos Cônicos, 34,78\% são Vasos Globulares e 17,39\% são Vasos de Borda Reta.

Quanto ao diâmetro das bocas dos vasilhames reconstituídos, 44,41\% estão entre 21 e $30 \mathrm{~cm}$ de $\varnothing, 29,41 \%$ entre 10 e $20 \mathrm{~cm}$ de $\varnothing, 23,52 \%$ entre 31 e $40 \mathrm{~cm}$ de $\varnothing$ e $2,94 \%$ acima de $40 \mathrm{~cm}$ de $\varnothing$.

\section{Maracanan}


No setor SE-A-0 e ampliações, foi encontrado um conjunto de cacos que permitiram a restauração de dois vasilhames, que confirmam as tendências observadas na análise das bordas: Vaso Cônico - pequeno vasilhame $(23 \mathrm{~cm}$ de h e $20 \mathrm{~cm}$ de $\varnothing$ ), cerca de $90 \%$ restaurado (faltando, basicamente, os cacos do fundo do vasilhame), paredes inclinadas para dentro, borda introvertida, queima de tendência oxidante e paredes finas $(0,9 \mathrm{~mm})$.

Vaso Globular - pequeno vasilhame $(11 \mathrm{~cm}$ de h e $14 \mathrm{~cm}$ de $\varnothing)$, cerca de $50 \%$ restaurado (sem o fundo e cerca da metade do bojo), paredes inclinadas para dentro, borda direta, queima de tendência redutora e paredes finas $(0,8 \mathrm{~mm})$.

Estes vasilhames, juntamente com outros cacos mais grossos, restaurados, mas que não permitiram identificação de forma, constituíam um sepultamento. Durante o processo de escavação do interior dos mesmos, foram observados pequenos pontos esbranquiçados em meio ao sedimento, mas impossíveis de serem recuperados. No entanto, foram coletados dentes humanos de uma arcada dentária infantil, correspondendo a uma criança com estimativa de idade biológica entre 3 e 4 anos, pelo estágio de formação das coroas dos dentes permanentes e ausência de raízes (não rompidos).



Figura 7: Vaso cônico reconstituído. 


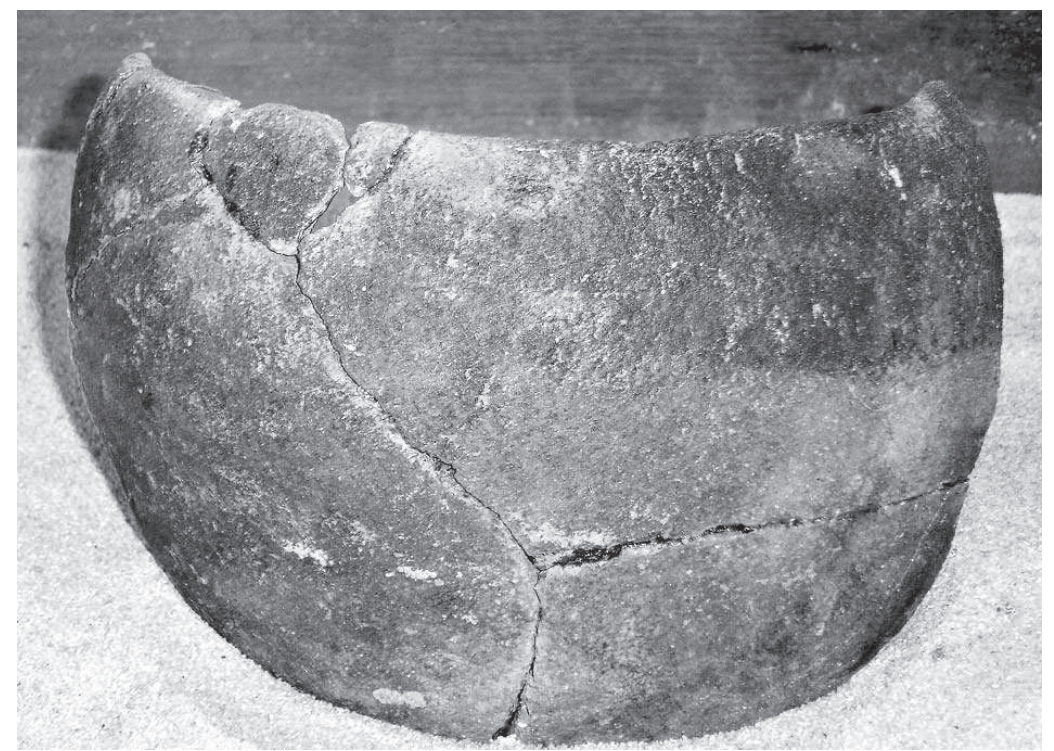

Figura 8: Vaso globular reconstituído.

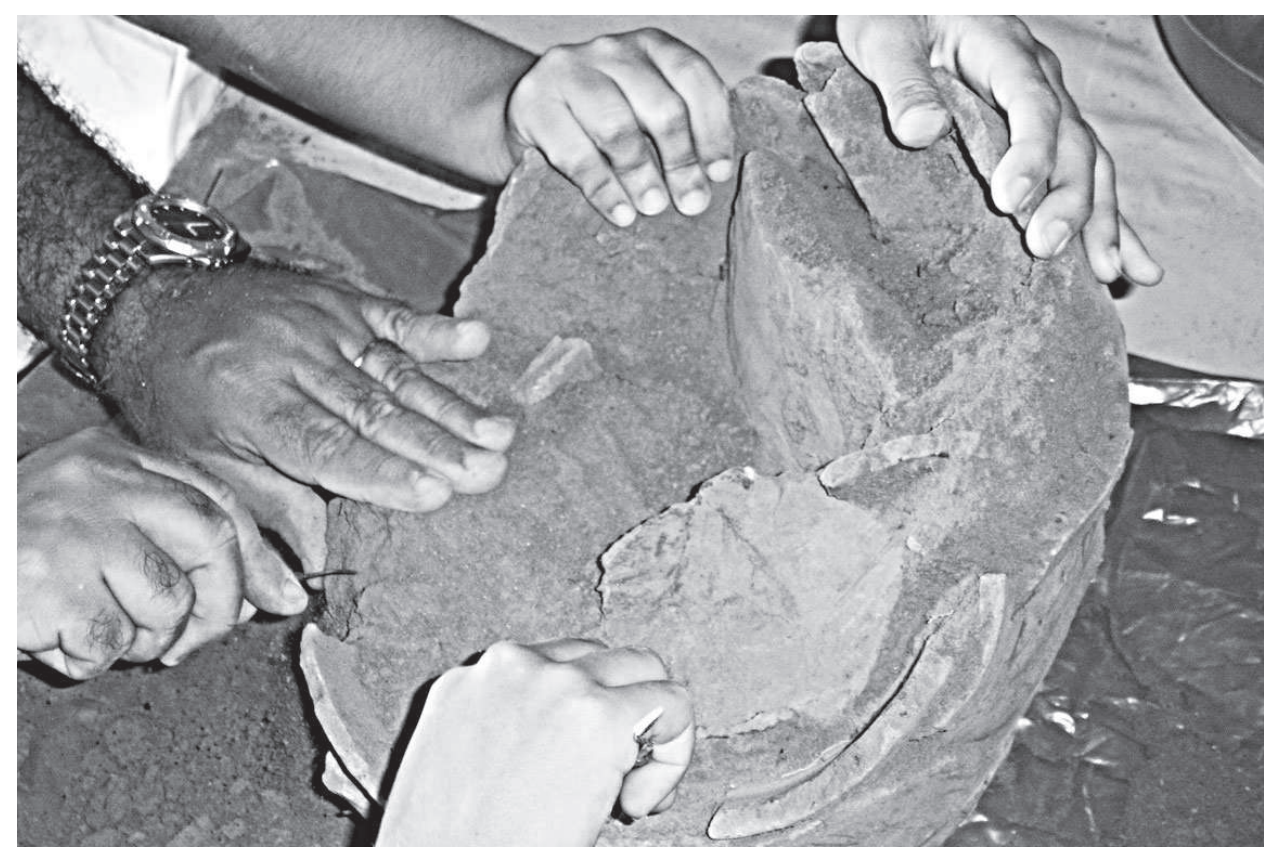

Figura 9: Escavação do vasilhame cerâmico em laboratório, utilizando-se instrumentos odontológicos.

\section{Maracanan}




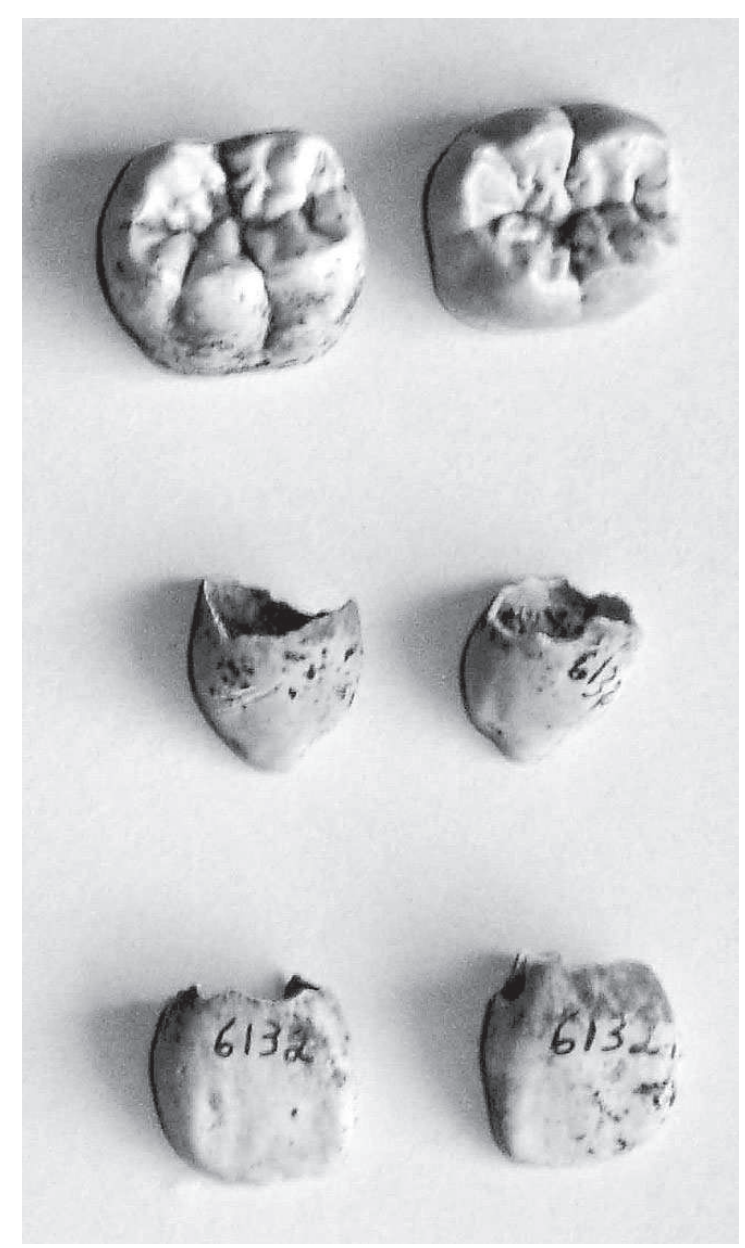

Figura 10: Dentes humanos encontrados no vasilhame cerâmico.

\section{OUTROS MATERIAIS CERÂMICOS}

Outros dois tipos de material cerâmico foram identificados no material. No setor SC-1, nível $0 / 10 \mathrm{~cm}$, localizou-se um fragmento de tembetá em cerâmica. A peça, fragmentada no eixo mais longo, tem $18 \mathrm{~mm}$ de comprimento, $10 \mathrm{~mm}$ de largura (10,5 $\mathrm{mm}$ no eixo transversal) e evidencia um característico tipo de adorno das populações indígenas. 


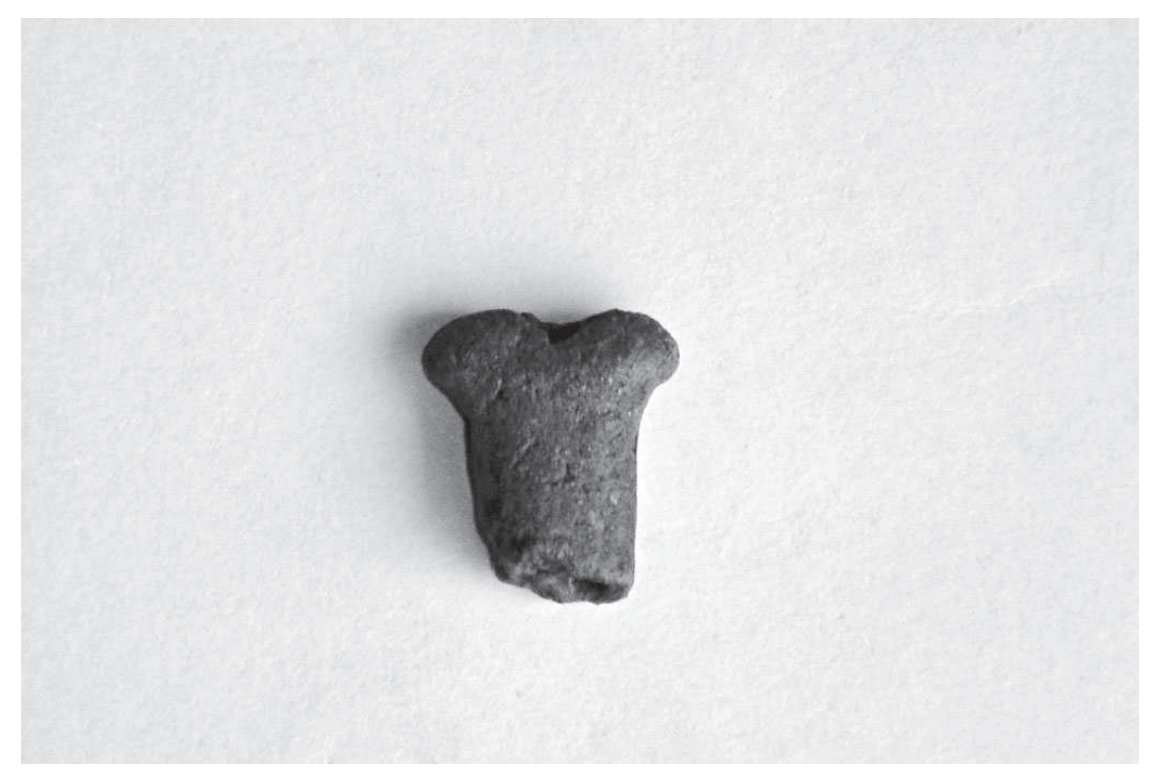

Figura 11: Tembetá fragmentado em cerâmica.

Já no setor SC-1, nível 0/10 cm, identificou-se um possível fragmento de fuso de fiar (cônico), evidenciando a prática da tecelagem pela população que ocupou o sítio.

\section{DISTRIBUIÇÃO DO MATERIAL NO SÍTIO.}

Todas as análises de distribuição do material (Distribuição Geral da Cerâmica, Distribuição da Cerâmica Simples, Distribuição da Cerâmica Decorada, Distribuição das Bordas, Distribuição das Bordas Decoradas), apontam uma concentração do material em torno do Marco Zero do sítio, expandindo-se por $120 \mathrm{~m}$ no eixo $\mathrm{N}-\mathrm{S}$ e cerca de $70 \mathrm{~m}$ no eixo L-0, devendo-se registrar que na direção L o sítio é interrompido pelo corte da estrada.

Tudo indica, portanto, que esta fosse a 'área core' da aldeia, ressaltando-se que o conjunto identificado como sepultamento, foi localizado praticamente no centro desta área. A Figura 12 mostra a concentração de material observada na escavação em relação a ocorrência de material registrada durante a prospecção.

\section{Maracanan}




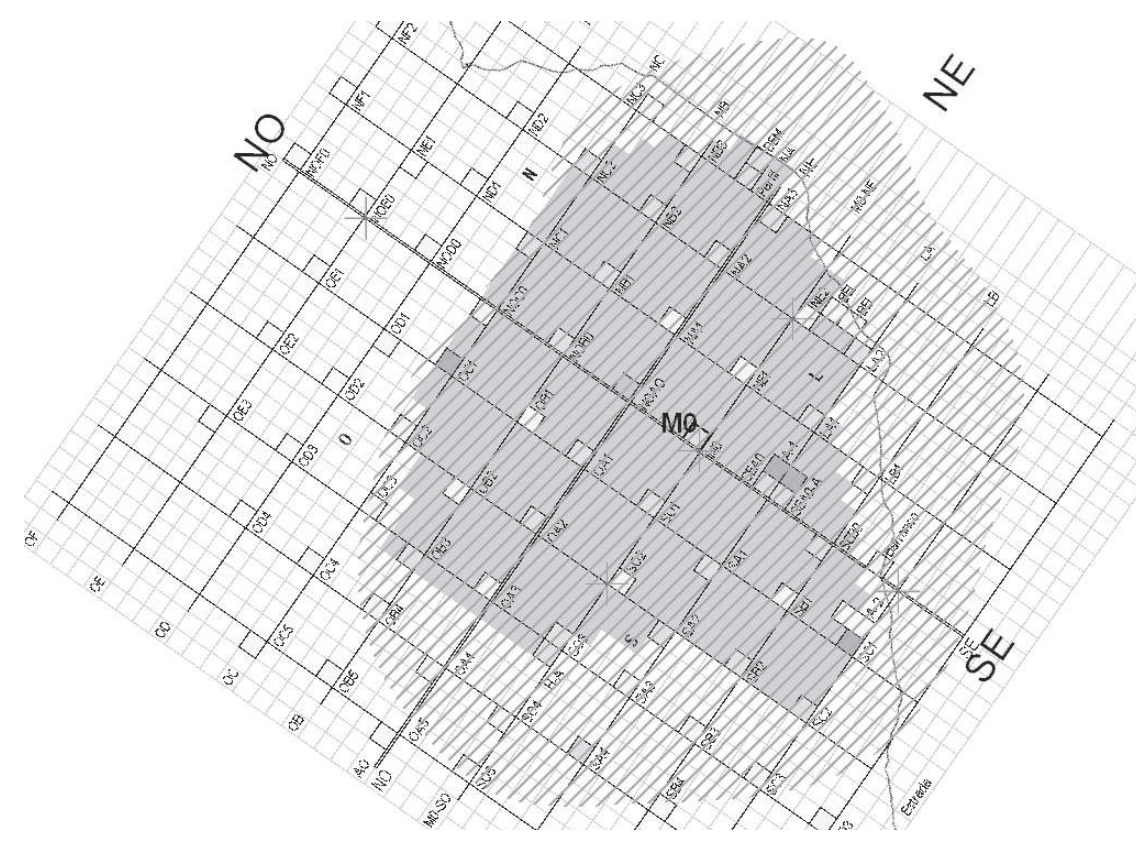

Figura 12: Área core do sítio identificada na escavação (em cinza) em relação a delimitação do sítio efetuada na prospecção (hachurado).

\section{DATAÇÕES}

As datações para o sítio em estudo foram realizadas pelo Laboratório de Vidros e Datação da Faculdade de Tecnologia de São Paulo, associada à UNESP. O método de datação absoluta utilizado foi a Termoluminescência (TL), uma vez que a cerâmica foi o vestígio coletado no sítio que melhor ofereceria resultados?

Os resultados obtidos dataram o sítio em cerca de 1.000 anos antes do presente (a.p.). A Tabela 1 apresenta as datações:

\begin{tabular}{|c|c|c|c|c|}
\hline Código LVD & Amostra & Setor & Nível & Idade \\
\hline 1913 & TL01 & SB2 & $0-10$ & $1200 \pm 250$ \\
\hline 1914 & TL02 & SC1 & $10-20$ & $1100 \pm 100$ \\
\hline 1915 & TL03 & Amplia. 2 & $10-20$ & $1300 \pm 300$ \\
\hline
\end{tabular}

Tabela 1: Resultados das datações por TL para o sítio Portocel. 
DISCUSSÃO DOS DADOS: FILIAÇÃO CULTURAL DO MATERIAL.

Ao longo das pesquisas arqueológicas no Espírito Santo, quatro tradições cerâmicas foram encontradas no Estado: a Tradição Una, a Tradição Aratu, a Tradição Tupiguarani e a Tradição Neobrasileira. Com estas últimas, o material analisado não guarda qualquer semelhança e, desta forma, não trataremos delas aqui.

A Tradição Una apresenta uma das cerâmicas mais antigas do Brasil fora da Amazônia: por volta de 3.500 anos A.P. ela já aparece na Gruta do Gentio, no Noroeste de Minas Gerais, dando início à Tradição ${ }^{8}$. Originária, possivelmente, da Amazônia, esta tradição expande-se por todo o Sudeste: partindo do noroeste de Minas Gerais, atinge o sul deste Estado, o norte de São Paulo, posteriormente, a Serra Fluminense, a Baixada de Campos e o litoral do Rio de Janeiro e, por fim, a serra do Espírito Santo. Ocupantes tanto de grutas (Minas Gerais e serras), como de sítios abertos, os grupos da Tradição Una eram portadores de uma cerâmica pequena, tecnologicamente bem feita, cor escura (devido à queima redutora), formas arredondadas (as mais antigas lembrando a forma de cabaças) e alguma decoração plástica. Acompanhando esta cerâmica, encontra-se material lítico (lascado, polido e picotado), adornos diversos e, nos sítios de maior preservação, abundante material têxtil e vegetal. Os sepultamentos apresentam uma grande variação entre as suas fases, inclusive com a prática da cremação ${ }^{9}$. Por volta de 1.000 anos A.P., esta Tradição também é encontrada em Goiás ${ }^{10}$ e, em torno de 950 A.P., no sudoeste da Bahia ${ }^{11}$.

No Espírito Santo, especificamente, Perota ${ }^{12}$, reconhece a Fase Tangui desta Tradição, em cinco abrigos e um sítio aberto, entre a região do rio Doce e Vitória. A fase, com datação de $1140 \pm 80$ anos A.P. ou 810 A.D., se caracteriza por uma cerâmica temperada com quartzo, hematita e mica, cor predominante preto-marrom escura, oxidação sempre incompleta e o 'alisamento com seixo ou feixes de capim deixou estrias muitas vezes profundas'. Além da cerâmica simples, identificou-se nos tipos decorados o Polido-Estriado e o Vermelho (Banho Vermelho). As formas reconstituídas são vasilhames geralmente globulares, tigelas fundas e rasas e as bordas são em sua maioria diretas.

A Tradição Aratu, por sua vez, tem sua origem no Nordeste brasileiro ${ }^{13}$. Identificada, inicialmente, na Bahia, estende-se também por Goiás, Espírito

\section{Maracanan}


Santo, Sergipe, provavelmente, Piauí e outros Estados do Nordeste. Embora as datações por C14 coloquem seu início, na Bahia, por volta de 1.080 anos A.P., deve ser mais antiga ali, pois, "nordestina", ela aparece no Espírito Santo por volta de 1.150 anos A.P. Caracteriza-se por grandes sítios habitação, todos a céu aberto, além de sítios cemitério, onde 'os grandes vasilhames usados para depositar os mortos formam verdadeiros campos de urna nas periferias das aldeias" ${ }^{14}$. Esta cerâmica, de grandes proporções, é tecnologicamente bem feita, predominantemente simples, ocorrendo alguma decoração plástica, formas esféricas e ovóides, de cor avermelhada (queima oxidante). Os vasilhames são vasos, tigelas e urnas funerárias piriformes. Além dos vasilhames cerâmicos, costumam aparecer bifaces polidos e cachimbos tubulares. Parece que os sítios eram erguidos próximos a matas galeria. Muito provavelmente, seriam grupos de horticultores semipermanentes, com agricultura incipiente do tipo floresta tropical (derrubada e queimada). A Tradição guarda muitas semelhanças com a Sapucaí, diferenciando-se desta por apresentar decoração e formas mais variadas, alguns padrões decorativos ausentes na outra, além de diferenças na distribuição das formas. Atualmente, alguns pesquisadores defendem que estas duas expressões formem uma única tradição ${ }^{15}$.

No Espírito Santo, Perota ${ }^{16}$ identificou duas fases desta Tradição. A primeira, a Fase Itaúnas, está representada por diversos sítios do litoral norte e central do Estado, com datações que vão de 800 a 1780 A.D. ${ }^{17}$. Os sítios, todos abertos ${ }^{18}$, estão nas proximidades das margens de rios $(50$ a $100 \mathrm{~m}$ ) ou a beira-mar, sobre pequenas elevações. A cerâmica é temperada com quartzo, ocorrendo ainda hematita e grafita e, raramente, conchas moídas, apresenta oxidação incompleta e um alisamento superficial, que deixava sempre estrias. Além da cerâmica simples, foram identificados nos tipos decorados o Vermelho (Banho Vermelho), Pintado, Corrugado, Polido-Estriado, Grafitado, Roletado, Ungulado, Inciso, Ponteado, Escovado e Entalhado. As formas reconstituídas são, em geral piriformes, com bordas inclinadas para dentro, peças de corpo globular com gargalo reto, esféricas de contorno simples e meia-calota. Perota' ${ }^{19}$, observa que esta Fase tem 'ligações com um sítio conhecido historicamente fundado por jesuítas a partir do ano de 1610'.

A segunda, Fase Jacareípe, está representada em sítios do litoral central do Estado (Chapada de Carapina), a $1 \mathrm{~km}$ da costa, com datações entre $605 \pm 70$ A.P. ou 1345 A.D. e $600 \pm 45$ A.P. ou 1350 A.D. Caracteriza-se por uma 
cerâmica temperada com quartzo, hematita e cacos de cerâmica moídos, bem compactada e alisada, com decoração plástica restrita a uma pequena faixa, sempre perto das bordas. Além da cerâmica simples, foram identificados nos tipos decorados o Corrugado, o Corrugado Ungulado, o Ponteado, o Roletado e o Ungulado. As formas reconstituídas mais comuns são as tigelas pequenas, recipientes globulares e cônicos, todos de pequenas dimensões, bases sempre arredondadas e cônicas.

Estabelecer uma fase arqueológica significa reconhecer a repetição de determinados elementos (os tipos) em todo o contexto cultural, inclusive o ecológico, com sua variação espaço-temporal. Por outro lado, uma vez que uma fase é reconhecida, determinados traços podem ser comparados entre si e se um conjunto de fase apresenta afinidades em aspectos como padrões de povoamento, tecnologia do material (nos aspectos gerais e particulares), formas de sepultamento, etc., elas podem ser agrupadas em tradições e foi assim que as Tradições Una e Aratu foram estabelecidas. Tradições, porém, sempre apresentam um considerável grau de dificuldade na sua determinação, tanto por sua, necessariamente, grande extensão espacial, quanto por sua persistência temporal. Por outro lado, deve-se reconhecer que as Tradições Culturais são dinâmicas e se elas têm um ponto de origem, na sua expansão espacial e persistência temporal elas ganham, perdem e criam características, estabelecem trocas, influenciam e são influenciadas. Representam, portanto, um verdadeiro processo histórico.

Desta forma, associar um sítio arqueológico diretamente a uma Tradição, como no presente caso, é sempre muito difícil e problemático. Contudo, trata-se de uma tentativa importante, pois permite entender-se ou delinear-se melhor a dinâmica cultural e o processo histórico da população que o sítio representa.

No caso do sítio Portocel, duas possibilidades de filiação cultural, apesar de toda a dificuldade, se apresentam: Tradição Una ou Tradição Aratu.

Tentando estabelecer as relações culturais da Fase Piumhy, da Tradição Una, Dias e Carvalho ${ }^{20}$, realizam um trabalho que nos parece extremamente útil para estabelecermos a filiação do material: apresentam quatro quadros sintéticos comparativos entre as Tradições Una, Sapucaí e Aratu: o I dos padrões de povoamento, o II de elementos característicos das Tradições e passíveis de comparação, o III dos tipos decorados e o IV da morfologia

\section{Maracanan}


dos vasilhames. Para nosso objetivo, não abordaremos os dados comparativos da Tradição Sapucaí. Para comparação das Tradições Una e Aratu, os autores utilizam dados das Fases Una (litoral do Rio de Janeiro), Mucuri (Serra Fluminense e foz do Paraíba do Sul), Piumhy (sul de Minas Gerais) e Tangui (Serra Capixaba), todas da Tradição Una, Aratu (Bahia), Itanhem (Bahia), Jacareípe (litoral central do Espírito Santo), Itaúnas (litoral centro-norte do Espírito Santo) e Cachoeira, da Tradição Aratu.

Nos padrões de povoamento, ambas apresentam sítios a céu aberto, no que se enquadra o sítio Portocel. Ocupação em abrigos-sob-rocha são exclusivos da Tradição Una, onde apenas a Fase de mesmo nome (litoral do Rio de Janeiro) não apresenta este tipo de sítio. Em relação ao ambiente, apenas as fases Una e Itaúnas, uma de cada Tradição, apresentam sítios em restinga. Toda a Tradição Una apresenta sítios associados à mata, assim com as Fases Aratu, Jacareípe e Itaúnas. Apenas a Fase Una apresenta sítios em praia e em mangues, enquanto que na Tradição Aratu as Fases Itanhem, Jacareípe e Itaúnas associam-se a estes ambientes. Sítios próximos a rios e lagos só não aparecem na Fase Itanhem e sítios cemitério são registrados nas Fases Mucuri, Tangui, Aratu e Itaúnas.

O sítio Portocel pode ser associado a ambientes de restinga, praia e, provavelmente, mata.

Em relação ao Quadro II, elementos característicos comparáveis, algumas informações começam a clarear nossa questão. Decoração restrita a borda, é registrada nas Fases Mucuri e Piumhy e em todas da Tradição Aratu, exceto a Fase Itanhem. Já a Decoração no Total da peça, aparece como exclusiva da Tradição Una (todas as fases). No sítio Portocel não pudemos observar decoração restrita à borda, mas é possível perceber a presença de decoração na totalidade do vasilhame (o Polido-Estriado, por exemplo). Os demais elementos utilizados no quadro (rodelas de fuso, cachimbos, instrumentos líticos e ósseos), são muito genéricos e, portanto, pouco comparáveis.

O Quadro III, tipos decorados, parece ser o mais significativo para nosso objetivo. Em primeiro lugar, deve-se ressaltar que Tradição Aratu possui uma variedade maior de decorações, sendo algumas exclusivas da mesma: Ungulado, Ponteado e Grafitado ${ }^{21}$. Destas, Ungulado e Ponteado estão presentes no sítio Portocel, o primeiro em percentual significativo. Corrugado-Ungulado e Corrugado-Ponteado (presentes no sítio Portocel, 
mas computados como Corrugado), são exclusivos das Fases Mucuri (certamente com ocorrência reduzida), Jacareípe e Itaúnas. Corrugado é comum a praticamente todas as Fases das duas tradições, assim como o Banho Vermelho.

Neste Quadro, três decorações merecem ser mais bem discutidas. A primeira é o Inciso, com percentual significativo de ocorrência no sítio: esta decoração parece ser característica da Tradição Aratu, aparecendo em três das suas fases, enquanto na Una aparece apenas na Fase Mucuri. Contudo, é com esta Fase do Rio de Janeiro que a Tangui (Espírito Santo), parece guardar mais relações. O segundo é o Roletado, não muito representado no sítio e que parece também característico da Tradição Aratu, ocorrendo em uma única Fase da Una, justamente a Tangui. Por fim, o Polido-Estriado, que inverte a situação: característico da Tradição Una (presente em todas as fases e com percentual significativo), aparece em uma única Fase da Aratu, a Itaúnas e é a decoração mais popular no sítio Portocel.

Ainda em relação à questão dos tipos, os autores ${ }^{22}$ ressaltam que, em todas as Fases da Tradição Una, o Tipo Simples representa de 80 a 95\% do material (99,1\% no sítio Portocel), enquanto a presença do Polido-Estriado varia entre 1,4 a $17 \%$ do material $(0,21 \%$ no sítio Portocel), sendo que seu percentual mais baixo (1,4\%) registra-se na sua fase litorânea (a Una).

Em relação ao último Quadro, o das Formas, infelizmente, por erro na impressão da publicação, a coluna das formas está em branco, o que impede a visualização de sua distribuição entre as Fases. Ressalta-se porém, que o vaso de corpo cônico e bordas diretas é comum nas Fases da Una e mais raro na Aratu. Contudo, "outras formas, comuns, são menos diagnósticas, como a vasilha globular e de boca constrita, comum a todas as fases (exceto a Itanhem) e a grande vasilha de corpo periforme, predominante na Aratu, mas também encontrada em todas as fases" ${ }^{\prime 23}$. As formas reconstituídas no sítio Portocel parecem se aproximar mais daquelas da Tradição Una.

\section{Considerações Finais}

A quantidade e qualidade dos vestígios, inesperadamente encontrados numa área que há décadas vem sendo afetada por atividades antrópicas,

\section{Maracanan}


reforçam a importância do levantamento e monitoramento arqueológico em áreas de futuros empreendimentos.

De acordo com os resultados obtidos para a análise da cerâmica, a maioria dos dados, sobretudo a decoração na totalidade dos vasilhames, o alto percentual de cerâmica simples associada à presença significativa do PolidoEstriado e as formas reconstituídas (além dos vasilhames restaurados), nos leva a associar o sítio Portocel a Tradição Una. Questões ligadas à queima, coloração da cerâmica e dimensões dos vasilhames também ajudam a corroborar esta visão.

A filiação do Sítio Portocel a Tradição Una, apesar de todas as dificuldades e perigos que isto representa, apresenta pelo menos dois pontos bem significativos.

Este é o primeiro registro de um sítio desta Tradição no litoral do Espírito Santo. Desta forma, fica demonstrado que esta Tradição extremamente instigante, representada por grupos de grande adaptabilidade e que iniciam sua trajetória/expansão nos cerrados Brasil Central (pelo menos do que temos registros) e termina por atingir o litoral do Rio de Janeiro, alcançou também o litoral do Espírito Santo.

Por outro lado, se associamos o material analisado a Tradição Una, parece-nos também inegável uma influência considerável da Tradição Aratu. A variedade de decorações, apesar de pouco populares, sobretudo a ocorrência significativa do Ungulado e do Inciso, além do Ponteado, bem como as combinações Corrugado-Ungulado e Corrugado-Ponteado. Deve-se ressaltar também, a presença de sítios da Fase Itaúnas (Tradição Aratu) nas proximidades do sítio Portocel.

Por fim, como observamos, os grupos da Tradição Una parecem ser extremamente adaptáveis, inclusive no que diz respeito às influências e trocas culturais $^{24}$. Talvez seja justamente esta a maior razão para a sua ampla distribuição espacial e longa duração.

O material lítico, representado predominantemente pelo quartzo em forma de pequenos fragmentos e lascas com tamanho reduzido, parece ter sido utilizado em atividades cotidianas relacionadas à subsistência do grupo, eminentemente vinculadas ao contexto ambiental. Podem ter sido usadas agrupadas e enfileiradas para descamar e limpar peixes, ralar raízes, etc., conforme sugere Menezes, responsável pela análise do material lítico ${ }^{25}$. 
Os vestígios malacológicos referem-se também à atividade de subsistência do grupo, que se servia sazonalmente de todos os recursos fornecidos pelo ambiente em questão. Apresentam-se fragmentados e aparentemente calcinados, distribuídos irregularmente sobre a superfície do sítio, principalmente nas áreas leste e nordeste do assentamento, mais próximos à costa.

As ocorrências de materiais históricos podem estar relacionadas a uma ocupação esporádica e mais recente do local, dada à pequena quantidade dos vestígios encontrados. Acrescente-se ainda a possibilidade de vinculação das mesmas com outros sítios históricos existentes nas circunvizinhanças. Ressalta-se que a colonização européia em Santa Cruz é das mais antigas do território capixaba, onde primeiro se estabeleceu o aldeamento jesuítico denominado 'Aldeia Velha', posteriormente transferido para Reis Magos, em Nova Almeida, ainda no século XVI. Referências a Barra do Riacho são também bastante antigas, remontando referências de ocupação colonial ao século XIX.

Os dentes humanos de criança de quatro anos de idade aproximadamente, encontrados durante a escavação em laboratório do até então denominado 'vasilhame' cerâmico, atestam que o grupo tinha o costume de enterrar seus mortos em urnas funerárias, pelo menos as crianças, e dentro do contexto habitacional. Além disso, pela idade estimada da criança, cujos ossos foram completamente destruídos por fatores ambientais, em relação ao tamanho da urna funerária (pequeno) podemos inferir que os ossos do indivíduo foram provavelmente depositados na urna, após a decomposição dos tecidos moles (enterramento secundário).

Quanto às datações obtidas, apesar de mais antigas do que a princípio esperado, uma análise mais atenta mostra que essas datas podem estar coerentes considerando-se um contexto mais amplo.

No Rio de Janeiro, uma falange proximal de mão de um indivíduo adulto, com resquícios de pele retirado do interior de uma urna do sítio Toca dos Urubus (Santa Maria Madalena), da Fase Mucuri (praticamente no mesmo ambiente da Tangui) foi datado por espectrometria de massa com aceleradores - MAS. Problemas com o acelerador durante a medida causaram uma grande barra de erro para o resultado: datada em $1430 \pm$ 400 anos A.P., a calibração do resultado gerou um intervalo de 2350 550 anos AP, abrangendo um longo período de tempo. Apesar da grande

\section{Maracanan}


barra de erro, o resultado mostrou que a ocupação era mais antiga do que se imaginava.

O sítio do Caju, situado no Município de Campos, norte do Estado do Rio, foi associado por Dias Jr. inicialmente a Fase Mucuri. Hoje, com o avanço dos estudos, esse pesquisador tende a considerar este sítio de Campos como uma outra expressão da Tradição Una (possivelmente Fase Ururaí). Por ser um único sítio, é difícil uma afirmação definitiva. Entretanto, os dados do Sítio do Caju são extremamente expressivos: ele foi escavado e é a maior aldeia pré-colonial conhecida no Estado do Rio de Janeiro (talvez no Brasil, fora da Amazônia), com uma riqueza imensa. Além dos materiais (cerâmica, lítico, ósseo, conchas), foi possível identificar estruturas habitacionais (pisos de cacos de cerâmica compactados - 'chãos de cabanas'; buracos de estacas - os maiores esteios de cabanas e as menores formando superfícies que podem ter sido cobertas e fogueiras com restos alimentares) e estruturas funerárias (em urnas, em covas forradas de cacos de cerâmica e direto no solo, sem qualquer acompanhamento, com os esqueletos envolvidos por cerâmica - como um 'sarcófago'). Este sítio tem uma datação de $1430 \pm 65$ anos A.P., o que é de grande relevância para o presente trabalho por ser em município próximo ao Espírito Santo, e em ambiente fora da serra, às margens do rio Paraíba, próximo à sua foz ${ }^{26}$.

A Fase Tangui, da Tradição Una, foi datada na região serrana do Espírito Santo em $1140 \pm 80$ anos A.P. ${ }^{27}$, e a Tradição Aratu, no estado, remonta a 1.200 A.P. ${ }^{28}$. Se a Tradição Una estava presente a 1.140 anos na região serrana, é possível estar no litoral por volta de 1.000 A.P., época em que já estaria sujeita a influência Aratu.

Janeiro | Dezembro 2011 
Notas e Referências

1 CEPEMAR Serviços de Consultoria em Meio Ambiente. Estudo de Impacto Ambiental - EIA - Expansão do Terminal do Portocel-Aracruz - ES. Relatório Técnico RT 053/00. Vitória, 2006.

2 Christiane Lopes MACHADO. Prospecção Arqueológica na Área do Projeto de Expansão da PORTOCEL, Aracruz / ES. Relatório de Pesquisa, Rhea Estudos \& Projetos Ltda / Cepemar Serviços de Consultoria em Meio Ambiente. Vitória, 2006.

3 Idem.

4 Para a descrição de todos os tipos utilizamos Igor CHMYZ et al. "Terminologia arqueológica brasileira para a cerâmica”. Cadernos de Arqueologia. Paranaguá: Mus. Arq. e Artes Pop., Universidade Federal do Paraná, n.1, 1976, p. 119-148.

5 O Banho Vermelho, mais que uma decoração, pode ser considerado um tratamento de superfície (para aplicação de pintura, p.ex.). Contudo, em amostras com pouco material decorado, como no presente caso, ele pode ser computado como decoração.

6 Os mesmos comentários feitos em relação ao Banho Vermelho servem para o Polido-Estriado.

7 Apesar de ter sido encontrado um fragmento de carvão de dimensões suficientes para datação, não foi enviado para datação devido a maior possibilidade de contaminação dessa amostra, uma vez que a área foi intensamente utilizada para silvicultura.

8 Ondemar DIAS Jr. "Una, Sapucaí, Aratu no Rio de Janeiro, em Minas Gerais, Goiás e áreas vizinhas". In: P.I. SCHMITZ; A.S. BARBOSA e M.B. RIBEIRO (edit.). Temas de Arqueologia Brasileira. Os Cultivadores do planalto e do litoral. Anuário de Divulgação Científica. Goiânia: IGPA/UCG, n. 9, v 5, 1978/79/80.

9 Lília CHEUICHE MACHADO. "Sobre as práticas funerárias de cremação e suas variações em grutas do norte e noroeste de Minas Gerais". Revista do CEPA. Santa Cruz do Sul: Faculdades Integradas de Santa Cruz do Sul, n.17 (20), p. 235-247, 1990.

10 Irmhild WÜST; Pedro Ignácio SCHMITZ. "Fase Jataí, estudo preliminar”. Anuário de Divulgação Científica. Goiânia: Gabinete de Arqueologia da

\section{Maracanan}


UCG, 1975, ano 2, n. 2, p. 71, 1975; I. SIMONSEN; A.P. OLIVEIRA; A. MENDONÇA DE SOUZA. "Seqüência arqueológica da bacia do Paranã - II. Sítios cerâmicos: a fase Palma". Arquivos do Museu de História Natural. Belo Horizonte: Universidade Federal de Minas Gerais, v. 6/7, p. 249-264, 1981/82.

11 Pedro Ignácio SCHMITZ et al. "Arqueologia nos cerrados do Brasil Central. Sudoeste da Bahia e Leste de Goiás. O Projeto Serra Geral". Pesquisas. São Leopoldo: Instituto Anchietano de Pesquisas, n. 52, Série Antropologia, 1996.

12 Celso PEROTA. "Resultados preliminares sobre a arqueologia da região central do estado do Espírito Santo". In: Programa Nacional de Pesquisas Arqueológicas. Resultados preliminares do quinto ano. 1969-70. Publicações Avulsas do Museu Paraense Emílio Göeldi, 26. MPEG, Belém, 1974.

13 Valentín CALDERÓN. "A fase Aratu no recôncavo e litoral norte do Estado da Bahia". PRONAPA. Belém: Pub. Av. do Mus. Pa. E. Göeldi, n.13, p. 161172, 1969

14 Pedro Ignácio SCHMITZ. "O Brasil Pré-Colonial”. Boletim do Instituto de Arqueologia Brasileira. Rio de Janeiro: IAB, 3, Série Catálogos, p. 27-31, 1987

15 P.I. SCHMITZ; A.S. BARBOSA; M.B. RIBEIRO. (edit.). Temas de Arqueologia Brasileira. Os Cultivadores do planalto e do litoral. Anuário de Divulgação Científica. Goiânia: IGPA/UCG, n. 9, v 5, 1978/79/80

16 Celso PEROTA. "Dados parciais sobre a arqueologia norte espírito-santense". Programa Nacional de Pesquisas Arqueológicas, Res. Prel. do Quarto Ano 1968/1969. Belém: Pub. Av. Mus. Paraense Emílio Goeldi, 26, 149-158, 1971

17 Irmhild WÜST. "Parque Estadual de Itaúnas: Diagnóstico Ambiental". In: SIMBIOS Consultoria Ambiental. Governo do Estado do Espírito Santo, Secretaria de Estado para Assessoria do Meio Ambiente. Julho, 2000.

18 Celso PEROTA. Op. cit., 1974, p. 133 refere-se a um sítio da Fase em abrigo-sob-rocha.

19 Celso PEROTA. "As datações do C-14 dos sítios arqueológicos do Espírito Santo". Revista de Cultura da UFES, vol.4, nº. Universidade Federal do Espírito Santo, Vitória, 1975.

20 Ondemar DIAS Jr.; Eliana T.CARVALHO. "A Fase Piumhi: seu reconhecimento arqueológico e suas relações culturais". Clio - Revista do Mestrado em História. Recife: Universidade Federal de Pernambuco, 1982, n.5: 5-43. 
21 Em publicação anterior Ondemar DIAS Jr. "Nota prévia sobre as pesquisas arqueológicas em Minas Gerais". Programa Nacional de Pesquisas Arqueológicas, Res. Prel. do Quinto Ano 1969/1970. Belém: Pub. Av. Mus. Paraense Emílio Goeldi, 26, 105-116, 1974, indica à ocorrência de ponteado-ungulado na Fase Piumhy, atribuindo sua presença a influência Tupiguarani.

22 Ondemar DIAS Jr. e Eliana T.CARVALHO.Op. cit. p. 30.

23 Ondemar DIAS Jr. e Eliana T.CARVALHO.Op. cit.

24 Paulo SEDA. "Uma história com muito mais de 500 anos: um breve panorama do povoamento pré-colonial do Rio de Janeiro". Anais do Museu Histórico Nacional. Rio de Janeiro: Mus. Hist. Nacional, V. 35, 15- 44, 2003

25 A análise do material lítico foi realizada pela Dra. Rosângela Menezes, do Instituto de Arqueologia Brasileira.

26 Ondemar F. DIAS Jr. "Pesquisas arqueológicas no sítio do Caju RJ-MP-8 (Campos dos Goitacazes)". Anais da Jornada de Trabalho do Laboratório de Análise do Processo Civilizatório. Campos: Universidade Estadual do Norte Fluminense/Centro de Ciências do Homem, p. 65-69, 1997

27 Celso PEROTA. Op. cit. 1975.

28 Celso PEROTA. In: Christiane Lopes MACHADO. Sítio Arqueológico Vila do Mutirão. Relatório de Pesquisa 042/06. RHEA Estudos e Projetos Ltda., 2006. 